\title{
KOCSÁNYTALAN TÖLGY POPULÁCIÓK FIATALKORI MAGASSÁGI NÖVEKEDÉSE SZIMULÁLT KLÍMAVÁLTOZÁS HATÁSÁRA, EGY SZÁRMAZÁSI KÍSÉRLETSOROZATBAN
}

\author{
Mátyás Csaba1', Kóczán-Horváth Anikó1, Antoine Kremer², \\ és Cuauhtémoc Saenz-Romero ${ }^{3}$ \\ ${ }^{1}$ Soproni Egyetem, Környezet- és Földtudományi Intézet \\ 2 Unité Mixte de Recherche Biodiversité Gènes \& Communautés (UMR 1202 BIOGECO), Institut National de la \\ Recherche Agronomique (INRA) - Université de Bordeaux, 69 route d'Arcachon, F-33610 Cestas, France \\ ${ }^{3}$ Universidad Michoacana de San Nicolás de Hidalgo, \\ Instituto de Investigaciones Agropecuarias y Forestales, Morelia, México
}

\begin{abstract}
Kivonat
A tanulmány kiválasztott kocsánytalan tölgy populációk szimulált klímaváltozásra adott fenotípusos válaszreakcióját (reakciónormáját) mutatja be egy, a francia INRA által kezdeményezett nemzetközi származási kísérlet 10 éves magassági adatai alapján. A reakciónormákat a klímatolerancia becslésére alkalmaztuk, az eredeti termőhelynél melegebb és szárazabb helyszíneken. Az egy irányban változó klímaviszonyokra adott válasz-regressziókat lineárisnak találtuk. A maximális növekedési potenciált a populációk alkalmazkodott termőhelyüknél kedvezöbb feltételek mellett mutatták. A különbözö klímákhoz adaptált populációk fenotípusos plaszticitása, vagyis klíma-érzékenysége szignifikánsan eltérő mértékünek bizonyult. A Kárpát-medencei származások a többi európai populációhoz képest átlagos teljesítményt mutattak. A szárazsági határhoz közelebbi populációk jobb klíma-toleranciája a szaporítóanyag felhasználás szempontjából a kísérlet legfontosabb eredménye. Az eredmények a "támogatott áttelepités/vándorlás" koncepcióját a kocsánytalan tölgy esetében megerősitik, és az alkalmazkodó erdőművelés országos stratégiája fejlesztéséhez felhasználhatók.
\end{abstract}

Kulcsszavak: alkalmazkodóképesség, kocsánytalan tölgy, klímatolerancia, származási kísérlet, reakciónorma.

\section{JUVENILE HEIGHT GROWTH RESPONSE OF SESSILE OAK POPULATIONS TO SIMULATED CLIMATIC CHANGE BASED ON PROVENANCE TEST DATA}

\begin{abstract}
The report presents the analysis of phenotypic response (reaction norm) of selected sessile oak populations to simulated climate change, based on 10-year height data from an international provenance experiment network initiated by INRA (France). Reaction norms were calculated for assessing tolerance of populations to (simulated) warmer and dryer conditions than at origin. The unilateral responses to waming and drying climatic conditions have been linear. The maximum growth potential of populations was shifted toward more favorable conditions than the original ones. Phenotypic plasticity of populations of various provenance, interpreted as an indicator of climate sensitivity, was found significantly different. The provenances from the Carpathian Basin have shown average performance compared to other European populations. The better phenotypic plasticity of populations originating closer to the xeric (trailing, lower) limit is the most important result of the analysis, in terms of reproductive material use. The results corroborate the concept of "assisted migration" for sessile oak and may support the development of a strategy for adaptive forest management.
\end{abstract}

Keywords: adaptability, phenotypic plasticity, climate tolerance, provenance test, assisted migration. 


\section{BEVEZETÉS}

A fafajok alkalmazkodó képességének határa a melegedő és szárazodó nyári klímához (Gálos et al. 2009) nem ismert, jövőbeni vitalitásukat és produkciójukat bizonytalanság övezi. Számos kutatásban elörevetítették már a vitalitás csökkenését, az elterjedési terület eltolódását, a különböző kártevők elszaporodását. Ezek a jelenségek különösen a fafajok alsó, szárazsági határán („xeric limit”) válnak komoly kihívássá az erdőgazdálkodás számára (Mátyás et al. 2010, Hlásny et al. 2014, Mátyás \& Sun 2014). Különösen fontos lenne a domináns, klímazonális, erdőtársulásainkat meghatározó fő fafajaink várható viselkedésének megbízható, kvantitatív elörebecslése, mint amilyen a kocsánytalan tölgy is. Széles termőhelytürése (Sáenz-Romero et al. 2018) a klímaváltozásra felkészülés egyik fontos fajává emeli (Czúcz et al. 2011, Borovics \& Mátyás 2013, Cseke et al. 2014).

Az erdészeti fafajokkal létesített származási kísérletek feltárták a genetikai változatosság jelentős mértéke mellett azt is, hogy az adataik a klímaváltozás által kiváltott válaszreakciók előrevetítésére is felhasználhatók. A megváltozott klímát eltérő klimatikus környezetbe telepítéssel szimulálhatjuk a származási kísérletekben (Mátyás \& Yeatman 1987, Mátyás 1994). A módszert azóta széles körben alkalmazzák, és tovább fejlesztették (Leites et al. 2012, Sáenz-Romero et al. 2016a, Rehfeldt et al. 2017), elsősorban az északi félgömb fenyő fajaira. Kísérleteink során erdeifenyő (Mátyás et al. 2007), lucfenyő (Ujvári-Jármay et al. 2016) és bükk (Horváth \& Mátyás 2016) fafajokra bemutattuk az elörebecslés lehetőségeit, kocsánytalan tölgyből azonban nem rendelkezünk megfelelő hazai kísérlettel. Egy EU-s projekt (FORGER) keretében lehetőség nyílt a francia INRA (A. Kremer) által kezdeményezett nemzetközi kocsánytalan tölgy származási kísérlet adatai elemzésére, amely azonban, elsősorban az adaptált módszer miatt nem szolgáltatott egyértelmű eredményt (Sáenz-Romero et al. 2016a), emiatt indokoltnak ítéltük a kísérleti adatok újraértékelését.

A tanulmányban bemutatjuk az új koncepció alapján végzett elemzést, amelynek célja adatok gyüjtése a kocsánytalan tölgy klímaváltozás során várható viselkedéséről. Ennek keretében vizsgáljuk a nyári szárazsághoz való alkalmazkodást, és a stresszválaszt jellemezzük a származási és kisérleti helyszínek nyári aszályvalószínüsége alapján. Az eredmények hozzájárulhatnak a klímaváltozásra felkészülés során a szaporítóanyag gazdálkodás stratégiájának továbbfejlesztéséhez (Mátyás 2016, Mátyás \& Kramer 2016, Sáenz-Romero et al. 2016b).

\section{ANYAG ÉS MÓDSZER}

A kocsánytalan tölgy (Quercus petraea) 116 európai ill. kisázsiai, őshonos állományaiból gyüjtött szaporítóanyaggal a francia INRA intézet, A. Kremer koordinálása mellett, nemzetközi együttmüködésben, négy év leforgása alatt (1990-1993, 1996) 23 helyszínen létesített származási kísérletet. A magassági felvételezések a különböző helyszíneken nem azonos időpontokban történtek, így a 2, 5, 7, 8, 11, 15 és 20 éves adatokból az adatsorokból számított növekedésmenet alapján, a 10 éves korra standardizált magasságot határozták meg. 
A kísérlet problémája, a származások kiegyenlítetlen képviselete mellett, az a körülmény, hogy érthető okokból a mintavételezett állományok, és a létrehozott kísérletek döntő része a fafaj atlanti, északnyugati elöfordulási területére koncentrálódik.

Mindamellett a kísérleti hálózat a fafaj legnagyobb reprezentatív keresztmetszetét képviseli, és nem valószínű, hogy a közeljövőben hasonló kezdeményezésre sor kerülhet. A kocsánytalan tölgy jelenlegi és a változó klímában betöltendő szerepe miatt az adatok kiértékeléséhez komoly érdek füződik, különösen Magyarország részéröl, amely a kísérlethez anyagot szolgáltatott, de a létesitésben nem vett részt.

Az összegyüjtött adatbázis anyagából eddig az u.n. „Madsen ${ }^{1}$ gyűjités” 14 populációját felhasználva, készült egy átfogó elemzés, ugyanis csak ezek a populációk szerepelnek megfelelő számú helyszínen (Sáenz-Romero et al. 2016a). Tanulmányunkban ugyanezen 14 db európai-kisázsiai származás, valamint a Kárpát-medencét képviselő populációk (1. táblázat) fiatalkori (10 éves) adatait az elöbbi elemzéstől eltérő statisztikai módszerekkel értékeltük. Az elemzés során a szimulált klímaváltozásra adott fenotípusos válaszreakciókat (reakciónormákat) hasonlítottuk össze.

A szárazsági határ mentén a klímaérzékenység megállapítása elsődlegesen fontos kérdés Magyarországon. Ebben a tekintetben előnyösnek bizonyult, hogy a kísérleti hálózatban nagyobb számban vannak jelen populációk és kísérleti helyszínek a fafaj áreájának északnyugati részéről, ami lehetővé tette az áttelepités hatásának elemzését, elsődlegesen, sőt majdnem kizárólagosan, a melegebb és szárazabb termőhelyi feltételek irányában. A magassági adatok kiértékeléséhez a kelet-középeurópai, kontinentális klímát aszályveszély szempontjából jellemző, ökofiziológiai alapon meghatározott indexet vettünk figyelembe (FAl, Führer et al. 2011, Führer 2017).

A teszthelyszínekre és a származásokra vonatkozó klímaadatok a ClimateEU (http://tinyurl.com/ClimateEU) adatbázisból származnak. Az ökológiai zóna besorolás az European Environmental Stratification térképe alapján történt (2. táblázat, Metzger et al. 2005). A reakciónormák értékeléséhez, az ökocsoportok helyett, a jobban jellemző FAI alapú csoportosítást alkalmaztuk (l. később, 3. táblázat).

A magassággal és a megmaradással legszorosabb összefüggést mutató klímaparamétereket Sáenz-Romero és munkatársai (2016a) a teljes kísérletre vonatkozóan meghatározták, ezek az éves és a vegetációs időre vonatkozó aszályindexek voltak (ADI és GSDI). Saját elemzésünkben változóként - fentebb említett okok miatt - a hazai környezetben bevezetett FAl indexet alkalmaztuk (Führer et al. 2011). Hasonlóan más indexekhez, a FAI más klimatikus feltételek mellett, pl. Északeurópában, a klíma jellemzésére kevésbé alkalmas. Alkalmazásának indoka a nagyon eltérő származások esetében is az, hogy a tanulmányban a nyári szárazságra adott stresszválaszt jellemezzük a származási és kisérleti helyszínek nyári klímája alapján, a FAl ugyanis ennek érzékeltetésére alkalmas.

A kísérleti helyszínenként meghatározott ökológiai (klimatikus) távolságot (Mátyás \& Yeatman 1987, 1992) használtuk fel a populációk reakciónormái független változójaként. Az

\footnotetext{
${ }^{1}$ Dán kutató, a kísérletsorozat kezdeményezője
} 
ökológiai távolság a kiválasztott klímaparaméterre vonatkozó különbség, amelyet a kísérleti helyszín és az eredeti származási helyszín adatából képezünk. Pozitív értéke a (szimulált) melegedést-szárazodást, a negatív a lehülést és csapadéknövekedést indikálja.

1. táblázat: A kiválasztott 14 európai kocsánytalan tölgy populáció és a három „pannon” származás alapadatai.

Table 1: Data of 14 selected European and 3 "Pannonian" sessile oak populations.

\begin{tabular}{|c|c|c|r|r|c|c|c|}
\hline $\begin{array}{c}\text { Származási } \\
\text { hely }\end{array}$ & Ország & $\begin{array}{c}\text { Földrajzi } \\
\text { szélesség }\end{array}$ & $\begin{array}{c}\text { Földrajzi } \\
\text { hosszúság }\end{array}$ & $\begin{array}{c}\text { Tszfm. } \\
(\mathbf{m})\end{array}$ & $\begin{array}{c}\text { Éves } \\
\text { közép- } \\
\text { hömérséklet } \\
\left({ }^{\circ} \mathbf{C}\right)\end{array}$ & $\begin{array}{c}\text { Éves } \\
\text { csapadék } \\
(\mathbf{m m})\end{array}$ & FAI \\
\hline Syców & POL & 51,18 & 17,93 & 210 & 8,0 & 577 & 4,7 \\
\hline Bercé & FRA & 47,81 & 0,39 & 157 & 10,5 & 712 & 6,8 \\
\hline Vouillé & FRA & 46,60 & 0,18 & 130 & 11,2 & 745 & 7,0 \\
\hline Luss & DEU & 52,83 & 10,32 & 110 & 8,2 & 692 & 4,8 \\
\hline Dreuille & FRA & 46,46 & 2,89 & 270 & 10,5 & 778 & 5,2 \\
\hline Bolu & TUR & 40,92 & 31,67 & 1200 & 8,6 & 721 & 7,5 \\
\hline Dymock & GBR & 51,95 & $-2,45$ & 70 & 9,6 & 717 & 5,7 \\
\hline Rantzau & DEU & 53,71 & 9,76 & 10 & 8,3 & 767 & 4,5 \\
\hline Londal & DNK & 56,07 & 9,6 & 25 & 7,5 & 736 & 5,0 \\
\hline Elmstein & DEU & 49,36 & 7,87 & 470 & 7,7 & 755 & 4,4 \\
\hline $\begin{array}{c}\text { Recklinghau- } \\
\text { sen }\end{array}$ & DEU & 51,77 & 7,17 & 75 & 9,4 & 818 & 4,4 \\
\hline Blakeney & GBR & 51,79 & $-2,49$ & 91 & 9,5 & 804 & 5,3 \\
\hline Bussières & FRA & 47,76 & 5,49 & 330 & 9,6 & 890 & 5,1 \\
\hline Hald Ege & DNK & 56,13 & 9,40 & 250 & 6,2 & 770 & 4,3 \\
\hline Pilis & HUN & 47,72 & 18,87 & 500 & 8,6 & 665 & 5,1 \\
\hline Nagybátony & HUN & 47,94 & 19,85 & 400 & 8,7 & 605 & 5,2 \\
\hline $\begin{array}{c}\text { Klostermari- } \\
\text { enberg }\end{array}$ & AUT & 47,41 & 16,55 & 310 & 8,8 & 669 & 4,6 \\
\hline
\end{tabular}

Bár a kísérletsorozat indításakor nem volt lehetőség hazai kísérlettel csatlakoznunk, Kárpát-medencei (pannon) származások is kerültek az európai hálózat egyes helyszíneire. Ebböl kettő a vezető szerző közremüködésével került be, a magyarországi Nagybátony és Pilis, egy pedig az országhatár közeléböl, a burgenlandi Borsmonostorból származik (Klostermarienberg). Mivel azonban ezek a populációk csak kevés kísérletben szerepelnek (Pilis 2, Nagybátony 3 helyen), ezért „pannon csoportként” összevonva, a két magyar származást és - azonos ökológiai besorolása alapján - az ausztriai-burgenlandi származást, Borsmonostort együtt értékeltük (utóbbi 8 helyen van képviselve). Ezen populációk szerepeltetését az indokolja, hogy a szárazsági határ közelében várható növekedési és esetleges mortalitási 
reakciók ökológiai és gazdasági jelentősége különösen nagy, de pontosan ezek a helyszínek vannak hiányosan képviselve a kísérletben (1. ábra).

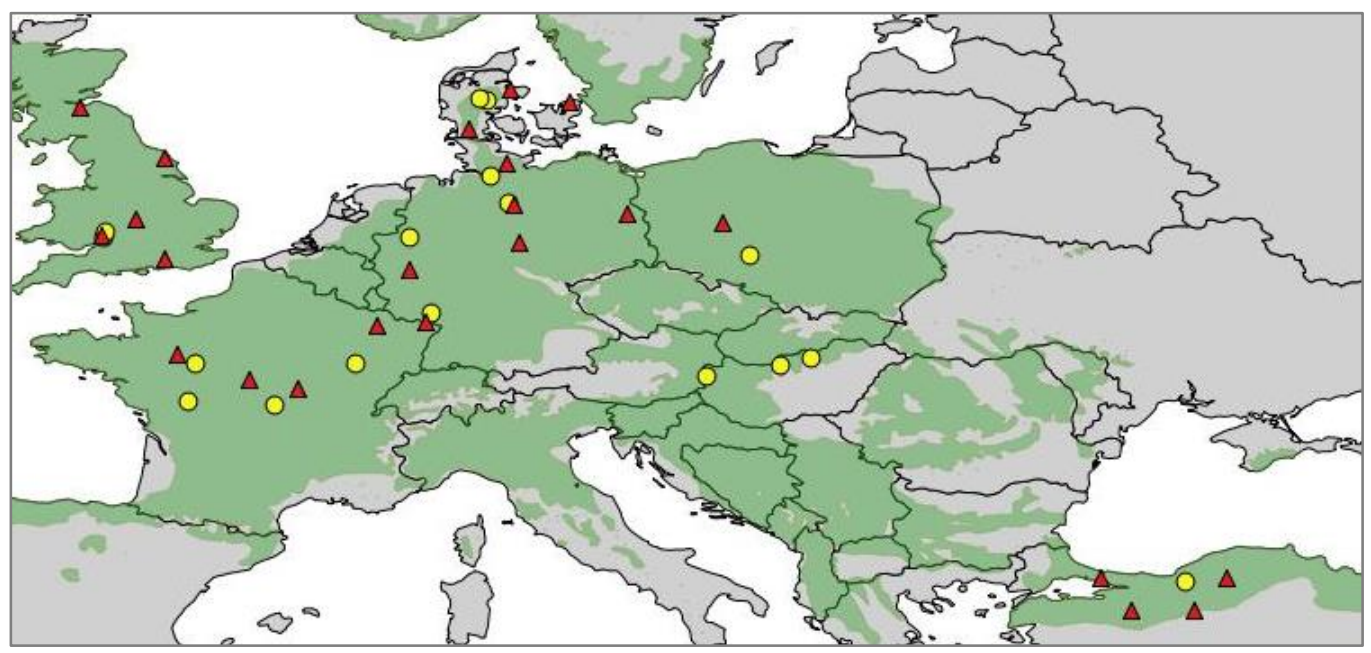

1. ábra: A kiválasztott kocsánytalan tölgy populációk $($ ) és teszthelyszínek $(\boldsymbol{\Delta})$ földrajzi elhelyezkedése a fafaj elterjedési területére vetítve (térkép: EUFORGEN).

Figure 1: Geographic location of the selected sessile oak populations $(\bigcirc)$ and test sites $(\boldsymbol{\Delta})$ projected on the distribution map of the species (source: EUFORGEN).

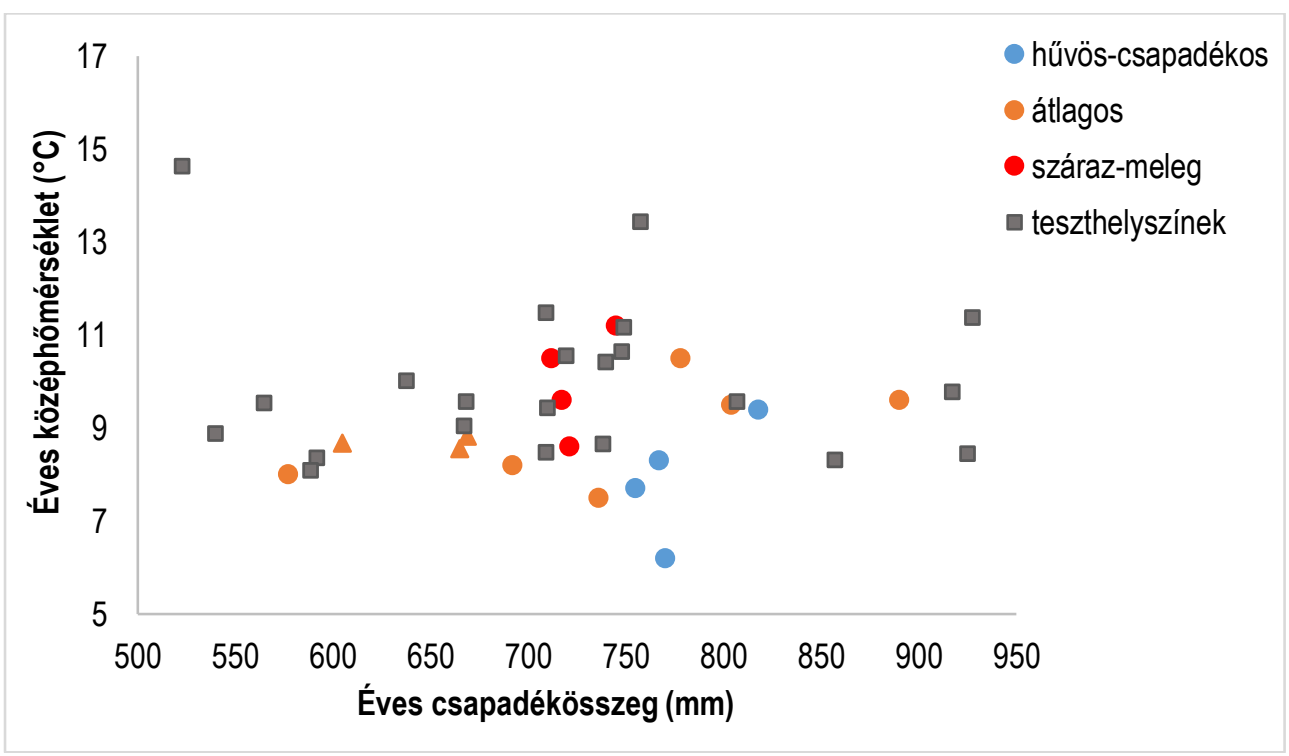

2. ábra: Az elemzésben szereplő származások és teszthelyszínek elhelyezkedése a klímatérben.

Az ábrán külön jelöltük a három FAl-csoportot ill. a „pannon” származásokat ( $\Delta$ ).

Figure 2: Location of populations and test sites in the climatic niche of annual precipitation ( $x$ axis) and mean annual temperature ( $y$ axis) divided into three climate groups classified by the FAl index.

Pannonian populations are marked by triangles. 
A 23 kísérleti helyszín többsége, a német, dán és angol kísérletek az 50. szélességtöl északabbra, atlanti klímában helyezkedik el. A kontinentális klímát egyedül a lengyel Kórnik képviseli. A legnagyobb és legjobban kezelt négy francia kísérlet a mérsékelt atlanti és nyugat-mediterrán, a török kísérletek pedig a kelet-mediterrán klímában helyezkednek el (2. ábra). A kísérleti helyszínek részletesebb adatai Sáenz-Romero et al. (2018) cikke mellékletében találhatók.

\section{EREDMÉNYEK, MEGVITATÁS}

\section{Klímastressz és a származások reakciónormája}

A reakciónorma alatt az ökológia egy adott faj, populáció vagy egyed (klón), változó környezeti feltételek mellett mért fenotípusos válaszát érti. Pontosabban, a reakciónorma a változó környezet és a genetikai adottság kölcsönhatását fejezi ki a fenotípusos tulajdonságban (pl. magasság, vagy fenológia), ezzel az alkalmazkodóképesség fontos jellemzője. A reakciónorma elméleti koncepciója és gyakorlati megjelenése között jelentős eltérés áll fenn. Általánosságban az eredeti (származási) termőhelyen intuitíve maximális reakciót várunk, és a reaciónorma függvény lefutását elméletileg a maximumtól mindkét irányban szimmetrikusan csökkenő, harang alakúnak tételezik fel (Rehfeldt et al. 2017). A gyakorlatban a függvény, az eddig vizsgált fafajok esetében, erősen asszimetrikusnak mutatkozik, a szárazodás-melegedés irányában exponenciálisan csökkenő, a hüvösebb-csapadékosabb irányban lassulva, de tovább javuló, majd hirtelen lecsökkenő trendet tételezhetünk fel (Czimber 2017).

A reakciónormák az eddigiekben elsősorban a nemesítésben kerültek alkalmazásra, pl. a szelektált klónok termőhelyállóságának, termőhelyi igényeinek megállapításához (Bach 1998). A klímaváltozással az eddig változatlannak vélt legfontosabb termőhelyi tényező, az éghajlat indult változásnak: ezzel a reakciónorma egyfajta elméleti jellemzőből hirtelen mindennapi gyakorlati tényezővé lépett elő, mert választ adhat arra a kérdésre, hogyan változik a faállomány vitalitása (növekedése, egészségi állapota, esetleg mortalitása) a termöhelyi feltételek változásával.

\section{A reakciónorma egyenletek vizsgálata}

A származások egyes kísérleti helyszíneken mért, 10 éves kori átlagos magassági adataival egyenként regressziót számoltunk, ahol a független változó a mindenkori helyszínre számított, FAl-val kifejezett, ökológiai távolság ( $\triangle F A l$ érték) volt, vagyis a populáció eredeti klimatikus feltételeitől való eltérés. A regresszió az ökológiai távolsággal, azaz a klímastressz növekedésével fellépő válaszreakciót a magassági növekedés (a függő változó) változásában adja meg. Az esetek döntő többségében az áttelepitéssel elöidézett (szimulált) klímaváltozás iránya a szárazodás/melegedés felé mutat, vagyis a kapott ökológiai távolsá- 
gok nagyrészt pozitívak. Elméletileg, egyirányú klimatikus változás mellett is a reakciónormát másodfokú egyenlet kellene hogy leírja (Mátyás et al. 2010), ehhez azonban, elsősorban a szárazsági határ közelében, nincs elegendő kísérleti helyszín és adat, ezért minden esetben lineáris egyenletet alkalmaztunk.

A populációk átlagadatai erősen szórnak, a kisérletek nagyon eltérő termőhelyi potenciálja (azaz termőhelyi/fatermési osztálya) miatt (3. ábra). Ennek csak egyik oka az eltérő klíma; a talaj- és hidrológiai viszonyok adatai - mint általában nemzetközi kísérletek esetében - itt is hiányoznak. Feltehetően hozzájárult a szóráshoz a magasság egységes 10 éves korra való vetítése is.

A regressziók a magassági variancia 10-40\%-át határozták meg (2. táblázat). Mivel a származások klímaérzékenységét a regresszió meredeksége jellemzi (4. ábra), valószínü ez a legérdekesebb jellemzője az egyenleteknek. A meredekség-elemzéshez a származásokat három csoportba soroltuk a $F A l$ értékek alapján: hűvös-csapadékos $(F A I<4,5)$, átlagos ( $F A / 4,5-5,5)$ és száraz-meleg ( $F A l>5,5)$ termőhelyi csoportokba. (Az ökológiai besorolás kevéssé veszi figyelembe a klíma szárazodását, ezért a $F A l$ értékek nem hozhatók fedésbe az ökológiai csoportokkal; így pl. a közép-atlanti (atc) zónába eső pontok eltérő FAI csoportokba kerültek (2. táblázat).

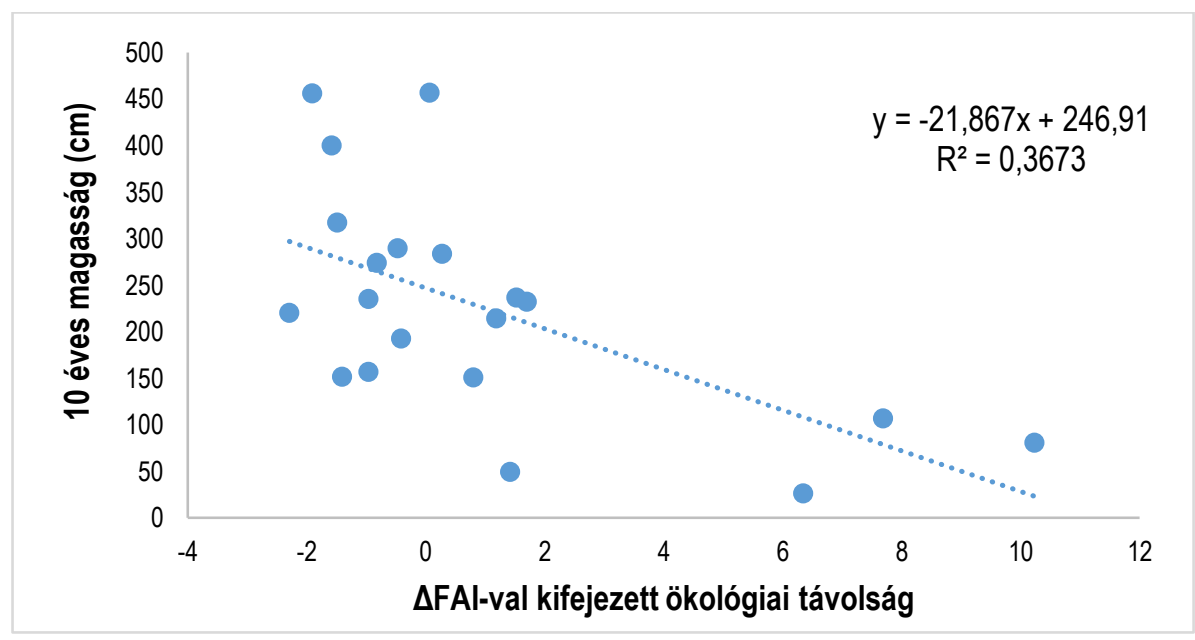

3. ábra: Egy atlanti-mediterrán (lusitán) származás (Vouillé, Franciaország; FAl: 6,982) 20 teszt helyszínen mért átlagmagassága az áttelepités ökológiai távolsága függvényében. Ez a származás az eredetinél hüvösebb/csapadékosabb helyszínekre is került (negatív $\triangle F A l$ értékek). Adatai az átlagosnál gyengébb szórást mutatnak, a regresszió a variancia 37\%-át magyarázza. A függvény meredeksége erős, vagyis a származás klímaérzékenysége magas (I. 3. táblázatot).

Figure 3: Mean height of an Atlantic-Mediterranean population (Vouillé, France; FAl: 6.98), in function of the ecological distance of transfer, expressed with the FAl index ( $\triangle F A I)$, measured at 20 test sites. Colder and more humid test sites than the original site have negative $\triangle F A$ I values. The regression explains $37 \%$ of the variation. The steep slope of the function indicates the high climate sensitivity of this provenance (see Table 3).

${ }^{2}$ ez a FAl érték Führer E. besorolása szerint tulajdonképpen már az erdőssztyep alsó peremére esik; a sztyep határ 7,25-nél van! 


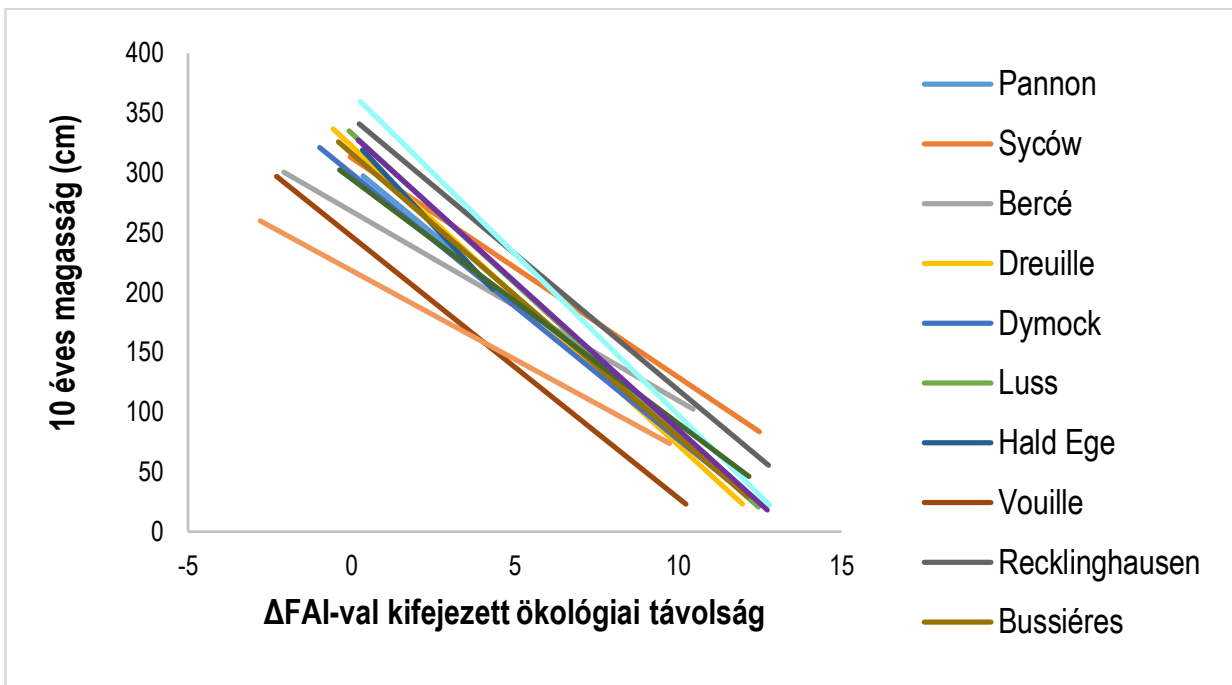

4. ábra: A vizsgált európai származások 10 éves kori magassága regressziója az áttelepités ökológiai távolságával ( $\triangle F A l)$.

Figure 4: Regression of 10-year height on ecodistance of transfer, expressed in Forestry Aridity Index change ( $\triangle F A l)$.

A meredekség és a FAl összefüggését ábrázolva, a brit Blakeney adatai, ismeretlen okból, kiugró szélső értékűnek bizonyultak. A származás kizárásával, a három FAl csoport között számított egyirányú varianciaanalízis az alacsony és magas FAl csoport között szignifikáns eltérést mutat (3. táblázat). Vagyis, a hűvösebb-nedvesebb helyszínek származásai (4,5 FAl alatt) nagyobb meredekséget mutatnak, a változásokra erősebben reagálnak, következőleg klímaérzékenyebbek. A szárazabb-melegebb termőhelyek populációi (5,5 FAI felett) plasztikusabbak, meredekségük szignifikánsan kisebb. A különbség a szárazsági határhoz közelebbi populációk jobb toleranciájára utal - ez a szaporítóanyag felhasználás szempontjából fontos jellemző (3. táblázat). 
2. táblázat: A vizsgált származások ökológiai jellemzői, magassága és reakciónorma paraméterei a származási hely klimatikus státusa szerint (a kísérletekben mért $\triangle F A l$ értékek és magasságok lineáris regressziójából számítva).

Table 2: Ecological characterisation and parameters of reaction norms of absolute and relative height vs ecological distance (expressed in $\triangle F A I$ values), listed according to the aridity index (FAl) at provenance.

\begin{tabular}{|c|c|c|c|c|c|c|c|c|c|}
\hline származás & $\begin{array}{c}\text { ökológiai } \\
\text { csoport }\end{array}$ & FAl & $\begin{array}{l}\text { FAl csop. } \\
\text { besorolás }\end{array}$ & $\begin{array}{l}\text { magassága } \\
(\mathrm{cm})\end{array}$ & meredekség & $\begin{array}{c}\mathbf{R}^{2} \\
\text { Szignif. }\end{array}$ & $\begin{array}{c}\text { relatív magasság } \\
(\%)\end{array}$ & meredekség & $\begin{array}{c}\mathbf{R}^{2} \\
\text { Szignif. }\end{array}$ \\
\hline Hald Ege & atn & 4,347 & hűvös & 329,0 & $-29,17$ & 0,105 & 101,7 & $-3,66$ & 0,130 \\
\hline Elmstein & atc & 4,412 & hűvös & 367,1 & $-26,94$ & $0,417^{* *}$ & 120,5 & $-3,47$ & $0,308^{*}$ \\
\hline Recklinghausen & atc & 4,449 & hűvös & 346,4 & $-22,78$ & $0,367^{* *}$ & 107,7 & $-0,79$ & 0,026 \\
\hline Rantzau & atn & 4,485 & hüvös & 332,5 & $-24,70$ & $0,393^{* *}$ & 109,7 & $-4,06$ & $0,333^{*}$ \\
\hline Syców & con & 4,727 & átlagos & 312,6 & $-18,34$ & $0,255^{*}$ & 102,8 & 0,19 & 0,003 \\
\hline Luss & atn & 4,759 & átlagos & 333,3 & $-25,10$ & $0,348^{* *}$ & 107,3 & $-3,48$ & $0,424^{* *}$ \\
\hline Pannon csop. ${ }^{b}$ & pan & 4,979 & átlagos & 305,6 & $-22,56$ & 0,091 & 98,8 & $-2,06$ & 0,039 \\
\hline Londal & atn & 5,048 & átlagos & 295,1 & $-20,46$ & $0,290^{*}$ & 95,1 & $-0,93$ & 0,064 \\
\hline Bussiéres & atc & 5,085 & átlagos & 316,5 & $-23,71$ & $0,428^{* *}$ & 110,9 & $-4,19$ & $0,458^{* *}$ \\
\hline Dreuille & atc & 5,244 & átlagos & 322,7 & $-25,03$ & $0,417^{* *}$ & 107,8 & $-2,64$ & $0,276^{*}$ \\
\hline Blakeney & atc & 5,318 & átlagos & 375.3 & $-37,98$ & 0,179 & 119,4 & $-5,38$ & 0,216 \\
\hline Dymock & atc & 5,658 & száraz & 300,0 & $-22,24$ & $0,324^{* *}$ & 108,1 & $-2,71$ & $0,364^{* *}$ \\
\hline Bercé & atc & 6,754 & száraz & 267,9 & $-15,82$ & 0,190 & 103,2 & $-2,49$ & 0,181 \\
\hline Vouille & lus & 6,978 & száraz & 246,9 & $-21,87$ & $0,367^{* *}$ & 92,9 & $-3,79$ & $0,534^{* *}$ \\
\hline Bolu & $\mathrm{mdm}$ & 7,478 & száraz & 218,4 & $-14,85$ & 0,222 & 84,6 & 0,08 & 0,000 \\
\hline
\end{tabular}

${ }^{a}$ a tengelymetszet értéke (intercept)

${ }^{b}$ három származásból átlagolt értékek

${ }^{*} p<0,05$

${ }^{* *} p<0,01$ 
3. táblázat: A származás szerinti FAl-csoportok meredeksége és tengelymetszete közötti különbségek szignifikancia-mátrixa (P értékek). A szignifikáns különbségeket vastagított számokkal jeleztük.

Table 3: Significance $(P)$ matrix of slope and intercept parameters of the different FAl groups.

Bold numbers indicate significant differences between groups of provenance.

\begin{tabular}{|c|c|c|c|c|c|}
\hline csoport & FAI & $\begin{array}{c}\text { átlagos } \\
\text { meredekség }\end{array}$ & $\mathbf{1}$ & $\mathbf{2}$ & $\mathbf{3}$ \\
\hline 1 & $>5,5$ & $-18,69$ & & 0,240 & $\mathbf{0 , 0 2 1}$ \\
\hline 2 & $4,5-5,5$ & $-22,53$ & & & 0,358 \\
\hline 3 & $<4,5$ & $-25,90$ & & & \\
\hline
\end{tabular}

\begin{tabular}{|c|c|c|c|c|c|}
\hline csoport & FAl & tengelymetszet & $\mathbf{1}$ & $\mathbf{2}$ & $\mathbf{3}$ \\
\hline 1 & $>5,5$ & 258,3 & & $\mathbf{0 , 0 0 7}$ & $\mathbf{0 , 0 0 0}$ \\
\hline 2 & $4,5-5,5$ & 323,0 & & & 0,187 \\
\hline 3 & $<4,5$ & 343,7 & & & \\
\hline
\end{tabular}

A 14 populáció származási helyszínére megállapított FAI érték is jól korrelál a meredekséggel (5. ábra). A hüvös-üde termőhelyű csoportba sorolt négy populáció meredeksége 24,70 és -29,17 közé esik, míg a legmagasabb FAl értékkel rendelkező Bolu (TR) meredeksége mindössze -14,85 (2. táblázat - nem minden regresszió bizonyult szignifikánsnak). Tehát a nagyon széles klimatikus amplitúdójú kísérleti helyszínek adatai alapján számított regressziók eltérései megerősítik a FAl csoportok között talált szignifikáns különbségeket (3. táblázat).

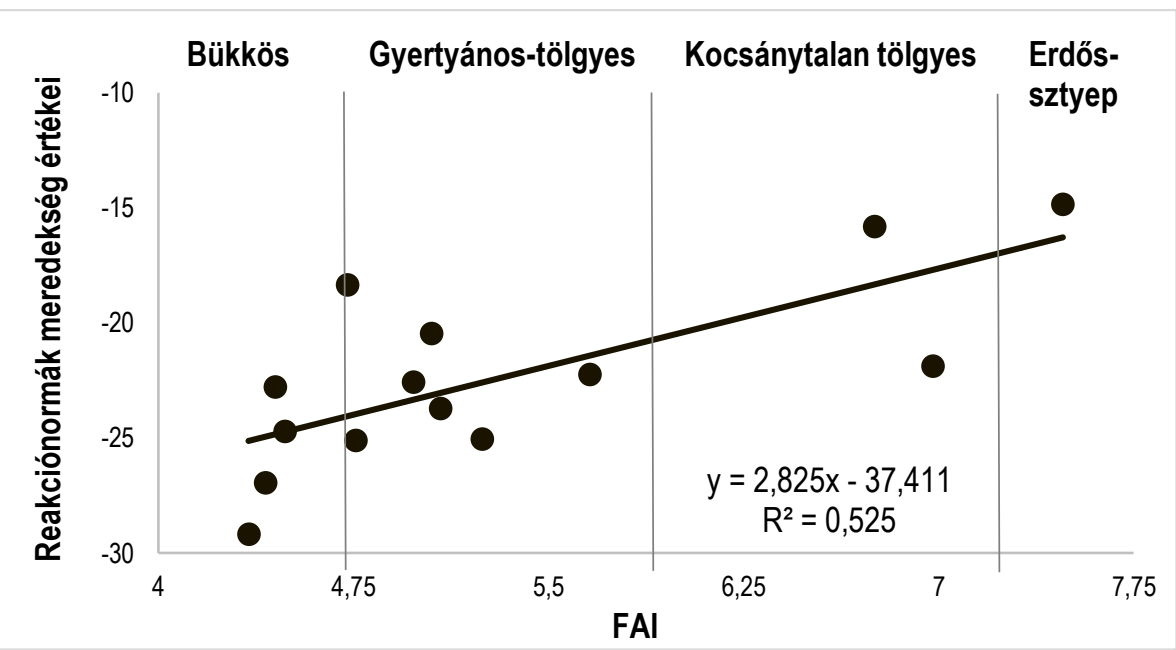

5. ábra: A származások reakciónormái meredekségének regressziója a származások eredeti FAl értékével, Blakeney származás nélkül. Feltüntettük a klimaosztályok FAl határait a klimatikus skála mentén.

Figure 5: Regression of slope values of reaction norms of populations (y axis) vs FAl values of original provenance (without Blakeney). The climatic scale is divided into forest climate classes of Hungary. 
A populációk fenotípusos plaszticitása mellett nem közömbös a tulajdonság kapcsolata a (juvenilis) növekedéssel. Ehhez a 10 éves magassági növekedést a származások klimatikusan meghatározott, „eredeti” klímájára standardizáltuk. Mivel a populációk eredeti származási helyén nem történhetett mérés, a regressziós egyenletek tengelymetszetét használtuk fel a "virtuális eredeti magasság” jellemzésére. Az egyenletek tengelymetszete (intercept) ugyanis a származási klímával azonos értékre, vagyis $0 \Delta F A l$ értékre megadja a származás virtuális „eredeti” magasságát, amelyet a származási helyével azonos klímában érne el, a teszthelyszínek termőhelyi potenciálja figyelembevételével. Feltűnő, hogy a száraz-meleg helyszínek populációi „eredeti” magassága rendre jelentősen elmarad a hüvös-csapadékos termőhelyekről származóktól (6. ábra).

A FAl-csoportokkal végzett egyirányú varianciaanalízis szerint (3. táblázat), a szárazabbmelegebb származások tengelymetszet alapján becsült magassága szignifikánsan elmarad az átlagos és hüvösebb-csapadékosabb termöhelyet jelző, alacsonyabb FAl értékű származások becsült magasságától. Az átlagos FAl értékü populációk viszont nem térnek el szignifikánsan a hűvösebb-csapadékosabb csoporttól. A szárazabb-melegebb helyről származó populációk növekedési potenciálja viszont rendre elmarad a kedvezőbb klímáról érkező származásokétól.

A populációk eredeti klímájával (FAl) számolva, az 6 . ábrán instruktív módon látható, hogy a tengelymetszettel jellemzett virtuális magasság a hüvösebb-csapadékosabb klímájú csoportban éri el legmagasabb értékeit, ugyanakkor a török Bolu a leggyengébb növekedést produkálja. Figyelembe kell természetesen venni, hogy a különbségek nem azonos termöhelyre vonatkoznak, de a kirajzolódó trend a származási csoportok jellemző klímájával öszszefügg. Mindenesetre a „virtuális magasság” egyúttal a származási helyszín spontán adaptáció ill. klímaszelekció révén előállt genetikai potenciálját képviseli.

A magyar olvasó számára kiemelten fontos lenne a pannon csoport fenotípusos plaszticitásának meghatározása. Sajnálatos módon, a kevés teszthelyszín miatt a számított regresszió eredmények nem megbízhatók. Annyi mindenesetre megállapítható, hogy a három populáció átlagos teljesítményt nyújt, mind virtuális magassága, mind a reakciónorma meredeksége szerint.

\section{Reakciónormák számítása relatív magassággal}

Relatív magasság alatt egy adott kísérletben mért teljesítménynek a kísérlet átlaga százalékában kifejezett értékét értjük. Előnye, hogy ezzel a lépéssel a helyszínek termőhelyi potenciál különbségéböl adódó szórását kiküszöböljük. A relatív magasság szemléletesen mutatja a termöhelyi-klimatikus spektrum mentén a plaszticitás különbségeit a származások között. A normalizálás annyiból nem pontos, hogy a származások összetétele nem minden kísérletben azonos, ennek ellenére tájékoztatást nyújt a populáció viselkedésére, változó klimatikus feltételek között. 


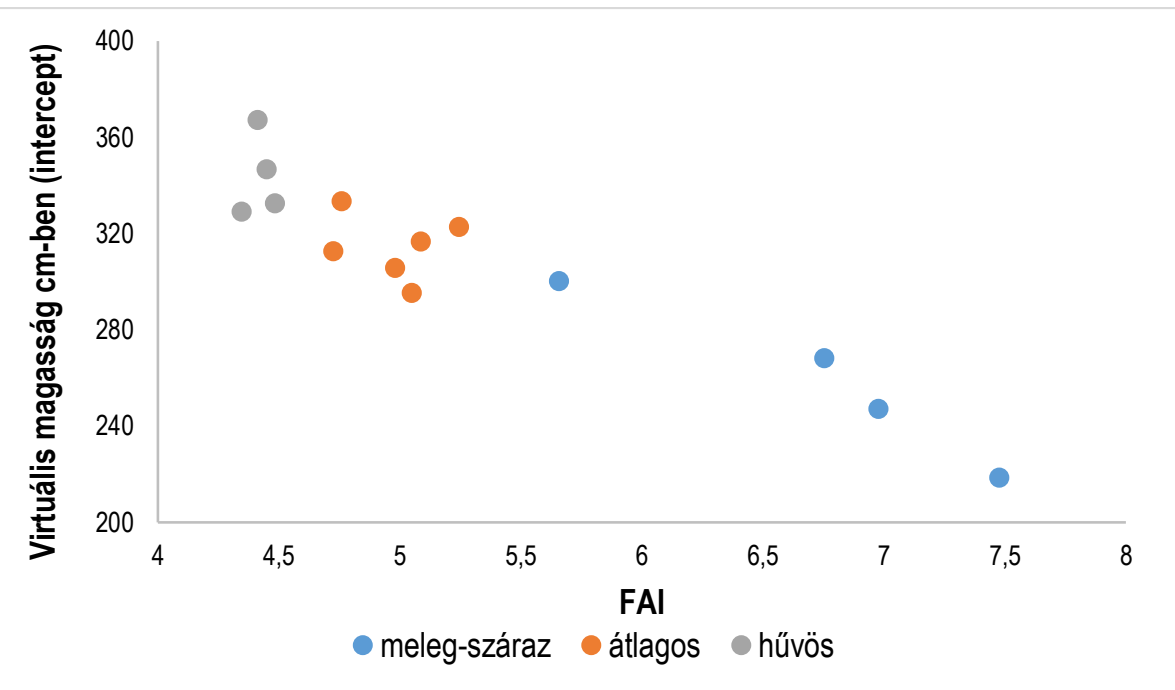

6. ábra: A vizsgált származások eredeti termőhelyére becsült, „virtuális magasságának” összefüggése a származási hely FAl értékével. A FAl csoportokat eltérő színek jelzik.

Figure 6: Estimated "virtual original height" (regression intercept, y axis) of populations vs FAl values of provenance. FAl groups are shown by colors.

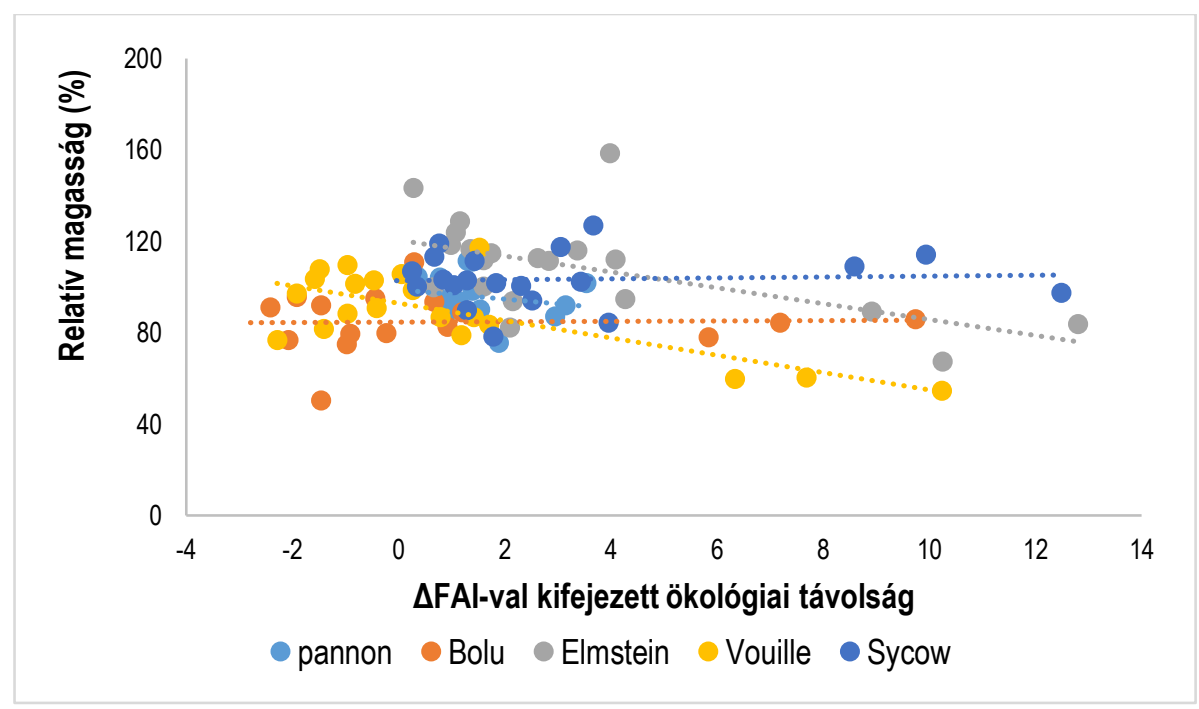

7. ábra: Néhány kiválasztott származás relatív magasságának regressziója az áttelepités ökológiai távolságával ( $\triangle F A l)$.

Figure 7: Regression of relative height vs ecodistance of transfer ( $\triangle F A l)$ of selected provenances.

A 7. ábrán néhány, jellegzetes klímából származó tölgy populáció relatív magassága regreszióját mutatjuk be, ezek különbségei nem túl meggyőzőek, értelmezésük csak korlátokkal fogadható el. A kontinentális Syców (PL) mutat kiegyenlítettebb, stabil teljesítményt. 
A hozzá hasonlóan stabil Bolu (TR) ugyanezt gyengébb növekedés mellett produkálja. A klimatikus feltételek változására érzékenyen reagáló atlanti Elmstein (DE) és az atlanti-mediterrán Vouillé (FR) is erőteljesebb növekedés-visszaesést mutat a szárazabb termőhelyeken a kísérleti helyszíneken képviselt többi származáshoz képest.

\section{Az eredmények jelentősége az alkalmazkodó erdőművelés stratégiája szempontjából}

Annak ellenére, hogy az európai (INRA) kocsánytalan tölgy származási kísérlet több mint húsz éves múltra tekinthet vissza, eddig csak egyetlen nemzetközi publikáció ismertette az eddig elért eredményeket (Sáenz Romero et al. 2016a), gyakorlati alkalmazási lehetőségek részletezése nélkül. Az értékelések elmaradásának számos oka van, az egyik az ilyen típusú kísérletek nemzetközi karakteréből adódó koordinációs nehézség: az adatgyüjtés összehangolása meghaladta a lehetőségeket. A könnyebben végrehajtható, és gyorsabban eredményeket produkáló fenyő kísérlethálózatokhoz képest a lombos fafajok több nehézséget támasztanak, ami feltehetöleg gyengítette az együttmüködésben való részvételt. A terepi adatfelvétekre támaszkodó kísérletezésnek nem tett jót az utóbbi évtizedek kutatási hangsúly eltolódása az intenzív, labor eredményekre építö, rövid lejáratú projektekből finanszírozott munkák irányába. Egy, lombos és fenyő tesztfafajokkal végzett elemzésünk (Sáenz-Romero et al. 2018) egyértelmüen igazolta, hogy a bükk és a kocsánytalan tölgy is szélesebb plaszticitással rendelkezik, mint a számos kísérletben elemzett luc- és erdeifenyő, ezért juvenilis eredményeik kevésbé látványosak. Viszont éppen a szélesebb fenotípusos plaszticitás miatt a kocsánytalan tölgy fontossága a klímaváltozásra készülés szempontjából kiemelkedő.

Az eddig csak genetikai oldalról elemzett közös tenyészkertek egyidejüleg egyfajta „fatermési kísérleti sornak" is felfoghatók, ahol genetikailag azonos összetételü és azonos korú faállományok növekedése és fatermése eltérő klimatikus/termőhelyi feltételek mellett vizsgálható. Több jel utal arra, hogy a származási kísérletek új értelmezése feltehetően felülírhatja a fafaj földrajzi elterjedése és termőhelyi-fatermési értékelése alapján feltételezett klímatoleranciáát (Czúcz et al. 2011, Berki et al. 2018, Illés 2018, Mátyás et al. 2018). E tekintetben a fentiekben számított reakciónormák a genetikai különbségek kimutatása mellett a termőhelyállóságra (reszilienciára), klímatoleranciára vonatkozó információkat is szolgáltatnak. Ez különösen fontos adat a jelentős többletköltséget és termesztési kockázatot jelentő „támogatott áttelepítés ill. vándorlás” megvalósíthatósága szempontjából. A szerzett tapasztalatok az alkalmazkodó erdőművelés országos stratégiája kialakítására, illetve a klímaváltozás döntéstámogató rendszere fejlesztésére használhatók fel (Bidló et al. 2014, Mátyás 2015, 2017, Mátyás \& Kramer 2016). Az alábbiakban összefoglalt eredmények alátámasztják a támogatott áttelepítés ill. vándorlás (assisted migration) koncepciójának indokoltságát. 


\section{ÖSSZEFOGLALÁS}

A vizsgált származási kísérlet hálózat eredményei nem véglegesek, de a 10 éves kori adatok már alkalmasak óvatos elörebecslésre (Lambeth 1980). A kísérleti hálózat adataiból elsősorban a faj általános toleranciájára, plaszticitására következtethetünk. Az egyes származások (populációk) magassági adataiból reakciónormákat számítottunk, ahol a független változó a FAI különbséggel kifejezett ökológiai távolság $(\triangle F A /)$ volt. Az áttelepítéssel szimulált klímaváltozás hatása - populációktól függően - a teljes magassági variancia 10-40\%-át határozta meg.

\section{A számított válaszregressziókból levonható általános, evolúciós-ökológiai következtetések}

A kapott regressziós egyenletek lineárisak, a fenotípusos válasz feltételezett exponenciális alakja nem volt kimutatható. Bár ezt az adatok jelentős szórása is előidézte, általánosságban bizonyosra vehető, hogy a változó klíma-tényezőre adott fenotípusos válasz nem szimmetrikus, jelentős szakasza lineáris, ezt a célállomány-tábla adatainak modellezése is megerösíti (Czimber 2017). A növekedés (produkció) optimuma nem az eredeti termöhelynek megfelelő klíma mellett, hanem annál üdébb, hűvösebb feltételek között várható, ezt fenyőkre vonatkozó, korábbi megfigyelések már jelezték (Namkoong 1969, Mátyás 1990).

A melegedés-szárazodás klimatikus transzekt mentén a növekedési ráta folyamatos, erőteljes csökkenése észlelhető. A növekedési ráta csökkenése a feltételezett optimumtól az üdébb-hűvösebb irányba feltételezhetően csak nagyobb ökológiai távolság esetén lép fel, ez a jelenleg elemzett adatbázis alapján nem ellenőrizhető. A válaszregressziók egyértelmüen bizonyítják, hogy a különböző származású (adaptáltságú) populációk fenotípusos plaszticitása a klimatikus-termőhelyi transzekt mentén eltérő mértékű. A klímaérzékenység mértékét, a más kísérletekben vizsgált luc- és erdeifenyöhöz képest, a kocsánytalan tölgy esetében kisebbnek találtuk, ezt más módszerrel kapott eredmények is megerősítik (SáenzRomero et al. (2018).

\section{Gyakorlati következtetések}

A vizsgálat legfontosabb eredménye, hogy a hüvösebb-nedvesebb helyszínek származásai nagyobb meredekségü reakciónormát mutattak, azaz a változásokra erősebben reagálnak, következőleg klímaérzékenyebbek. A szárazsági határhoz közelebbi populációk kisebb érzékenysége, vagyis jobb klíma-toleranciája a szaporítóanyag felhasználás szempontjából fontos információ. Ez a tény megerősíti, hogy a szárazsági határhoz közelebb eső, de nem szélsőségesen degradálódott populációk áttelepitése a klímatürést (reszilienciát) 
javíthatja, feltehetőleg a fenotípusos plaszticitást meghatározó génváltozatok (allélek) nagyobb gyakorisága miatt. Ennek valószínűségét korábbi vizsgálataink már felvetették (Borovics \& Mátyás 2013, Cseke et al. 2014).

A reakciónorma egyenlet az eredeti termöhelyi potenciálhoz alkalmazkodott növekedési ráták standardizált összehasonlitására is lehetőséget ad. A tengelymetszet $0 \Delta \mathrm{FAl}$ értékre megadja a származás virtuális, „eredeti” magasságát, az összes vizsgált termőhelyen mért teljesítmény figyelembevételével standardizálva, de természetesen a mindenkori származási hely klímájának megfelelően. Ez a virtuális magasság az egyes származási helyszínek spontán adaptáció, ill. klímaszelekció révén megvalósult potenciálját képviseli. A támogatott áttelepítés során előnyben részesített szárazabb-melegebb termőhelyek populációinak jövőbeli becsült (virtuális) magassági növekedése természetszerüen el fog maradni a hűvösebb-csapadékosabb termőhelyen tenyésző, alacsonyabb FAl értékű termőhelyek származásai jelenlegi magasságától.

Mivel a Kárpát-medencei populációk telepítési helyszínei aránylag szűk termőhelyi spektrumot fognak át, értékelésük csak a nemzetközi mezőnybe illesztve végezhető. $A$,pannon csoport" fenotípusos plaszticitását tekintve, az európai populációkhoz képest átlagos teljesítményt nyújt, mind virtuális magassága, mind a reakciónorma meredeksége szerint.

A válaszregressziós egyenletekből levezethető a ökológiában már elfogadott egyensúlytalanság; esetünkben ez azt jelenti, hogy a maximális növekedési potenciált az alkalmazkodott populáció termőhelynél kedvezőbb feltételek mellett produkálja; azaz a „helyi nem biztos, hogy a legjobb". Ez természetesen csak a mesterséges felújitással létrehozott állományok esetében igazolható.

Az elemzés általános hiányossága a szárazsági határon fellépő mortalitás előrevetítésének hiánya. Erre vonatkozó, megbízható adat nem állt rendelkezésre. A megmaradás fiatalkori értékei a helyi kezelés, technológiai eltérések és hibák által a legerősebben befolyásolt jellemző és alig hagy lehetőséget a helyi klimatikus hatások elemzésére.

Az analízis hiányosságaival és megbízhatóságával kapcsolatosan még számos további felvetés tehető, pl. a vizsgálati módszerek alkalmassága, a kísérletbe vont populációk és helyszínek összetétele stb. Nem szabad azonban megfeledkezni arról, hogy a vizsgált adatbázis egy olyan kísérlethálózat eredménye, amely, minden korlátja mellett, a fafaj genetikai alkalmazkodóképességének eddig legalaposabb elemzését teszi lehetővé, amelyhez hasonlót a jövőben a kutatás elörelátható finanszírozási körülményei aligha fognak lehetővé tenni. Ezért tettünk kísérletet az értékelés más szempontú megismétlésére, vállalva a fiatalkori adatok kétségtelenül nagy bizonytalanságát is. Bár a kísérleti anyag a hazai populációk tekintetében kevés közvetlen információt szolgáltat, meggyőződésünk, hogy a levont következtetések a hazai populációkra is érvényesek, és olyan tapasztalatokat kínál a feltételezett klímaváltozással kapcsolatban, amelyet semmilyen más módszerrel nem lehet helyettesíteni. Erdeink jövőjéről sajnos semmi biztosat sem tudhatunk. A klímaváltozásra adott válaszszal kapcsolatos bármilyen, akár nagy bizonytalansággal terhelt adat is több a puszta vélelmezésnél. 


\section{KÖSZÖNETNYILVÁNÍTÁS}

A kutatás megvalósítását segítette $C$. Sáenz-Romero részére az INRA-Bordeaux-i tartózkodást finanszírozó Mexikói Tudomány és Technológiai Tanács (CONACyT, 232838-as projekt) és a Michoacán-i Egyetem támogatása, továbbá a soproni tanulmányúthoz segítséget nyújtó EU-s FORGER projekt. Mátyás Csaba és Kóczán-Horváth Anikó kutatómunkáját a "VKSZ_12-1-2013-0034- Agrárklima.2" projekt támogatta.

\section{FELHASZNÁLT IRODALOM}

Bach I. 1998: Tájékoztató eredmények a fajta (genotípus) x termőhely kölcsönhatás vizsgálatáról. in: Tóth B. (ed): A Nemzetközi Nyárfa Bizottság (International Poplar Commission) 20. ülése és tanulmányútja Magyarországon. Az Erdészeti Tudományos Intézet Kiadványai, 9: 112-114.

Berki I., Móricz N., Rasztovits E., Gulyás K., Garamszegi B., Horváth A. et al. 2018: Fapusztulással párhuzamosan tapasztalt gyorsuló növekedés kocsánytalan tölgyeseinkben. Erdészettudományi Közlemények 8(1): 119-130. DOI: 10.17164/EK.2018.008

Bidló A., Király A. \& Mátyás Cs. (eds) 2014: Agrárklíma: Az elörevetitett klímaváltozás hatáselemzése és az alkalmazkodás lehetöségei. Nyugat-magyarországi Egyetem Kiadó, Sopron.

Borovics A. \& Mátyás Cs. 2013: Decline of genetic diversity of sessile oak at the retracting (xeric) limits. Annals of Forest Science 70(8): 835-844. DOl: 10.1007/s13595-013-0324-6

Cseke K., Jobb Sz., Koltay A. \& Borovics A. 2014: Tölgypusztulás genetikai szerkezetre gyakorolt hatása. Erdészettudományi Közlemények 4(2): 135-148.

Czimber K. 2017: Fafaj és fatermőképesség elörebecslése gépi tanulással, a célállománytáblák felhasználásával. Erdészeti Lapok 152(11): 348-349.

Czúcz B., Gálhidy L. \& Mátyás Cs. 2011: Present and forecasted xeric climatic limits of beech and sessile oak distribution at low altitudes in Central Europe. Annals of Forest Science 68(1): 99-108. DOl: 10.1007/s13595-011-0011-4

Führer E., Horváth L., Jagodics A., Machon A. \& Szabados I. 2011: Application of a new aridity index in Hungarian forestry practice. Időjárás 115(3): 205-216.

Führer E. 2017: Az erdészeti klímaosztályok úi lehatárolása öko-fiziológiai alapon. (A klímaváltozáshoz alkalmazkodó erdőgazdálkodás kihívásai III.) Erdészeti Lapok 152(6): 173-175.

Gálos B., Lorenz Ph. \& Jacob D. (2009): Klímaváltozás - Szélsőségesebbé válnak-e száraz nyaraink a 21. században? Klíma-21 füzetek 57: 56-63.

Hlásny T., Mátyás Cs., Seidl R., Kulla L., Merganicová K., Trombik J. et al. 2014: Climate change increases the drought risk in Central European forests: what are the options for adaptation? Lesnicky Casopis Forestry Journal 60: 5-18. DOI: 10.2478/forj-2014-0001

Horváth A. \& Mátyás Cs. 2016: The decline of vitality caused by increasing drought in a beech provenance trial predicted by juvenile growth. South-east European Forestry 7(1). 21-28. DOI: 10.15177/seefor.16-06

Illés G. 2018. A klímaváltozás nyomán bekövetkező fatermésváltozás becslése a kocsánytalan tölgy példáján. Erdészettudományi Közlemények 8(1): 105-118. DOI: 10.17164/EK.2018.007 
Lambeth C. 1980: Juvenile-mature correlation in Pinaceae and implications for early selection. Forest Science 26(4): 571-580. DOI: $10.1093 /$ forestscience/26.4.571

Leites L.P., Rehfeldt G.E., Robinson A.P., Crookston N.L. \& Jaquish B.C. 2012: Possibilities and limitations of using historic provenance tests to infer forest species growth responses to climate change. Natural Resources Modeling 25: 409-433. DOI: 10.1111/j.1939-7445.2012.00129.x

Mátyás Cs. 1990: Adaptation lag: a general feature of natural populations. Invited lecture. Proc., WFGA IUFRO Symp. Olympia, Wash. Paper no. 2.226, 10 p.

Mátyás Cs. 1994: Modelling climate change effects with provenance test data. Tree Physiology 14: 797-804. DOI: 10.1093/treephys/14.7-8-9.797

Mátyás Cs. 2015: Az alkalmazkodó erdőművelés támogatása. Az Agrárklíma projekt döntéstámogató rendszere. Erdészeti Lapok 150(4): 102-104.

Mátyás Cs. 2016: Guidelines for the choice of forest reproductive material in the face of climate change. FORGER Guidelines, Bioversity International, Rome, 2016. DOI: 10.13140/RG.2.1.1329.3207

Mátyás Cs. (eds) 2017: A klímaváltozáshoz alkalmazkodó erdőgazdálkodás kihívásai. (Cikksorozat az Erdészeti Lapokban) - I. rész 152(4): 102-106; II. rész 152(5): 134-136; III. rész 152(6): 173-177; IV. rész 152(9): 270-272; V. rész 152(10): 306-310.

Mátyás Cs. \& Yeatman C.W. 1987: A magassági növekedés adaptív változatosságának vizsgálata $P$. banksiana populációkban: Investigation of adaptive height growth variation of jack pine (Pinus banksiana Lamb.) populations. Erdészeti és Faipari Egyetem Tudományos Közleményei 1987(1): 191-197.

Mátyás Cs. \& Yeatman C.W. 1992: Effect of geographical transfer on growth and survival of jack pine (Pinus banksiana Lamb.) populations. Silvae Genetica 41(6): 370-376.

Mátyás Cs., Nagy L. \& Ujváriné Jármay É. 2007: Klimatikus stressz és a fafajok genetikai válaszreakciója az elterjedés szárazsági határán: elemzés és elörejelzés. In: Mátyás Cs. \& Vig P. (eds): Erdő és klíma V. Nyugat-magyarországi Egyetem, Sopron, 241-256.

Mátyás Cs., Nagy L. \& Újvári-Jármay É. 2010: Genetically set response of trees to climatic change, with special regard to the xeric (retreating) limits. Forstarchiv 81: 130-141.

Mátyás Cs. \& Sun G. 2014: Forests in a water limited world under climate change. Environmental Research Letters 9: 085001. DOI: 10.1088/1748-9326/9/8/085001

Mátyás Cs. \& Kramer K. 2016: Az erdei génkészletek szerepe a klímaváltozáshoz alkalmazkodó gazdálkodásban. Erdészettudományi Közlemények 6(1): 7-16. DOI: 10.17164/EK.2016.001

Mátyás Cs., Berki I., Bidló A., Csóka Gy., Czimber K., Führer E. et al. 2018: Sustainability of forest cover under climate change on the temperate-continental xeric limits. Forests 9(8): 489. DOI: 10.3390/f9080489

Metzger M.J., Bunce R.G.H., Jongman R.H.G., Mücher C.A. \& Watkins J.W. 2005: A climatic stratification of the environment of Europe. Global Ecology and Biogeography 14: 549-563. DOI: 10.1111/j.1466822x.2005.00190.x

Namkoong G. 1969: Nonoptimality of local races. Tree Improvement and Genetics - Southern Forest Tree Improvement Conference, Houston, 149-153.

Rehfeldt G.E., Leites L.P., Joyce D.G. \& Weiskittel A.R. 2017: Role of population genetics in guiding ecological responses to climate. Global Change Biology 24(2): 858-868. DOI: 10.1111/gcb.13883

Sáenz-Romero C., Lamy J.B., Ducousso A., Musch B., Ehrenmann F., Delzon S. et al. 2016a: Adaptive and plastic responses of Quercus petraea populations to climate across Europe. Global Change Biology 23(7): 2831-2847. DOI: $10.1111 / \mathrm{gcb} .13576$

Sáenz-Romero C., Lindig-Cisneros R.A., Joyce D.G., Beaulieu J., St. Clair J.B. \& Jaquish B.C. 2016b: Migración asistida de las poblaciones forestales para la adaptación de árboles ante el cambio climático (Assisted migration of forest populations for adapting trees to climate change). Revista Chapingo Serie Ciencias Forestales y del Ambiente 23(3): 303-323. DOI: 10.5154/r.rchscfa.2014.10.052 
Sáenz-Romero C., Kóczán-Horváth A., Nagy L., Ujvári-Jármay É., Ducousso A., Kremer A. et al. (): Common garden comparisons confirm inherited sensitivity differences between conifer and broadleaved forest tree species to changing climate. Peer Journal (benyújtva, lektorálás alatt).

Ujvári-Jármay É., Nagy L. \& Mátyás Cs. 2016: The IUFRO 1964/68 Inventory Provenance Trial of Norway Spruce in Nyírjes, Hungary - results and conclusions of five decades. Acta Silvatica \& Lignaria Hungarica 12(special issue): 178. DOI: 10.1515/aslh-2016-0001

Érkezett: 2018. május 1.

Közlésre elfogadva: 2018. május 30. 